\title{
Oral Administration of Probiotics Increases Paneth Cells and Intestinal Antimicrobial Activity
}

\author{
Silvia I. Cazorla1,2, Carolina Maldonado-Galdeano ${ }^{1,2}$, Ricardo Weill ${ }^{3}$, Juan De Paula ${ }^{4 *}$ \\ and Gabriela D. V. Perdigón ${ }^{1,2 *}$ \\ 1 Laboratorio de Inmunología, Centro de Referencia para Lactobacilos (CERELA-CONICET), San Miguel de Tucumán, \\ Argentina, ${ }^{2}$ Cátedra de Inmunología, Facultad de Bioquímica, Química y Farmacia, Universidad Nacional de Tucumán, \\ San Miguel de Tucumán, Argentina, ${ }^{3}$ Departamento de Investigación y Desarrollo, DANONE, Buenos Aires, Argentina, \\ ${ }^{4}$ Servicio de Gastroenterología, Hospital Italiano de Buenos Aires, Buenos Aires, Argentina
}

OPEN ACCESS

Edited by:

Sarah Lebeer,

University of Antwerp, Belgium

Reviewed by:

José María Landete,

Instituto Nacional de Investigación y

Tecnología Agraria y Alimentaria

(INIA), Spain

Analia Graciela Abraham,

Centro de Investigación y Desarrollo

en Criotecnología de Alimentos (CIDCA), Argentina

*Correspondence:

Juan De Paula

juan.depaula@hospitalitaliano.org.ar Gabriela D. V. Perdigón perdigon@cerela.org.ar

Specialty section:

This article was submitted to

Food Microbiology,

a section of the journal

Frontiers in Microbiology

Received: 02 January 2018

Accepted: 28 March 2018

Published: 16 April 2018

Citation:

Cazorla SI, Maldonado-Galdeano C,

Weill $R$, De Paula J and

Perdigón GDV (2018) Oral

Administration of Probiotics Increases

Paneth Cells and Intestinal

Antimicrobial Activity.

Front. Microbiol. 9:736.

doi: 10.3389/fmicb.2018.00736
The huge amount of intestinal bacteria represents a continuing threat to the intestinal barrier. To meet this challenge, gut epithelial cells produce antimicrobial peptides (AMP) that act at the forefront of innate immunity. We explore whether this antimicrobial activity and Paneth cells, the main intestinal cell responsible of AMP production, are influenced by probiotics administration, to avoid the imbalance of intestinal microbiota and preserve intestinal barrier. Administration of Lactobacillus casei CRL 431 (LC 431) and L. paracasei CNCM I-1518 (Lp 1518) to 42 days old mice, increases the number of Paneth cells on small intestine, and the antimicrobial activity against the pathogens Staphylococcus aureus and Salmonella Typhimurium in the intestinal fluids. Specifically, strong damage of the bacterial cell with leakage of cytoplasmic content, and cellular fragmentation were observed in S. Typhimurium and S. aureus. Even more important, probiotics increase the antimicrobial activity of the intestinal fluids at the different ages, from weaning (21 days old) to old age (180 days old). Intestinal antimicrobial activity stimulated by oral probiotics, do not influence significantly the composition of total anaerobic bacteria, lactobacilli and enterobacteria in the large intestine, at any age analyzed. This result, together with the antimicrobial activity observed against the same probiotic bacteria; endorse the regular consumption of probiotics without adverse effect on the intestinal homeostasis in healthy individuals. We demonstrate that oral probiotics increase intestinal antimicrobial activity and Paneth cells in order to strengthen epithelial barrier against pathogens. This effect would be another important mechanism by which probiotics protect the host mainly against infectious diseases.

Keywords: probiotics, antimicrobial activity, Paneth cells, intestinal fluids, intestinal microbiota

\section{INTRODUCTION}

The epithelium of the intestine is the largest surface area exposed to the outer environment, including pathogens, toxins, and foods. More than $1 \times 10^{14}$ symbiotic microorganisms live in the human intestinal lumen. Nevertheless, intestinal infection or translocation of bacterial agents is an exception rather than the rule and is mostly limited to highly pathogenic bacteria or predisposing disease states. In order to face this challenge, mammalian intestine minimizes contact between 
luminal microorganisms and intestinal epithelial cells surface, through the development of key elements: mucus, IgA, and antimicrobial peptides (AMPs) (Hooper and Macpherson, 2010). Paneth cells, a characteristic epithelial cell of the small intestine located at the bottom of the intestinal crypts, are responsible for the secretion of a diverse arsenal of AMPs like lysozyme, secretory phospholipase A2 (sPLA2), defensins, defensin-like peptides (elafin and SLPI) and cathelicidins, which have a high antimicrobial activity.

Antimicrobial peptides are small molecules, generally smaller than 40 amino acids (aa), whose aa composition, net charge (generally cationic), as well as their amphipathic and size characteristics, favor their interaction with lipid bilayers, mainly those that form the cytoplasmic membranes of pathogens like fungi and protozoa (Nakamura et al., 2016).

Difference in the design of the membranes of microbes and multicellular animals' allow AMPs to specifically target microorganisms. Bacterial membranes are organized in a way that the outermost leaflet of the bilayer is heavily populated by lipids with negatively charged phospholipids head groups. In contrast, the outer leaflet of eukaryotic's membranes is composed principally by lipids without net charge; most of the lipids with negatively charged head groups are segregated into the inner leaflet, facing the cytoplasm (Zasloff, 2002; Sankaran-Walters et al., 2017).

The expression, secretion, and activity of epithelial AMPs are tightly controlled through multiple transcriptional and post-transcriptional mechanisms (Mukherjee and Hooper, 2015). Studies on germ free mice have demonstrated that some intestinal AMPs are expressed independently of the microbiota signals (Putsep et al., 2000). While others, stored in secretory granules, are released into the intestinal lumen on stimulation with microbe-associated molecular patterms (MAMPs) and inflammatory cytokines [e.g., interleukin (IL)-1 $\beta$, tumor necrosis factor alpha (TNF- $\alpha$ ) and IL-22] (Ayabe et al., 2000; Habil et al., 2014).

Several reports offered concrete insight into the multiple functions of AMPs from Paneth cell to protect against pathogen colonization and controlling microbiota composition and localization. Namely, (i) mice deficient in matrix metalloproteinase 7 (MMP-7), the Paneth cell $\alpha$-defensin-processing enzyme, are highly susceptible to bacterial pathogens (Wilson et al., 1999); (ii) transgenic mice overexpressing the $\alpha$ - human defensin 5 (HD5) are protected against an oral challenge with Salmonella Typhimurium, with a significant increase in their survival (Salzman et al., 2003); (iii) in vivo depletion or down regulation of RegIII- $\gamma$, markedly decreases the killing of Listeria monocytogenes and vancomycin-resistant Enterococcus (Brandl et al., 2007, 2008); (iv) in both MMP-7 deficient and in $\alpha$-defensin 5 (DEFA5) $+/+$ mice, the microbiota composition in the small intestine was dramatically different from that of the wild-type strain (Salzman, 2010); and (v) genetic defects associated to decreased AMPs production can be related to intestinal inflammation and disease (Wehkamp et al., 2005; Cadwell et al., 2008; Koslowski et al., 2010). In addition to their antimicrobial role, AMPs have been shown to act as chemoattractants for cells of innate and adaptive immunity, and so, many authors consider them as a bridge between innate and adaptive immunity (Steinstraesser et al., 2011; Rivas-Santiago et al., 2013).

In the last century, probiotics have gained more and more interest as alternatives to stimulate the immune system, restricting the use of antibiotics or anti-inflammatory drugs. Probiotics are defined by the FAO/WHO as live microorganisms which, when administered in adequate amounts, confer a health benefit on the host. There are several benefits set for probiotics: protection against infections (Acurcio et al., 2017; Mallina et al., 2017; Park et al., 2017), prevention of cancer (Aragón et al., 2015), regulation of peristalsis, reduction of symptoms associated with lactose intolerance (Pakdaman et al., 2016), decrease in gut inflammatory response (Fábrega et al., 2017) and prevention of allergy (Vélez et al., 2015; Nelson, 2016). Most of these profits have been associated to the modulation that probiotics or fermented milk elicit in innate as well as the acquired immune system (Maldonado Galdeano et al., 2015; Igarashi et al., 2017).

In the present work we explore in a murine model whether Paneth cells and the antimicrobial intestinal activity are influenced by probiotics oral administration, in order to kill pathogens and strengthen the intestinal barrier integrity. Additionally, we investigate probiotics effects along the lives of the mice on AMP production, mainly on aging animals.

\section{MATERIALS AND METHODS}

\section{Bacteria}

Lactobacillus casei CRL 431 (Morata de Ambrosini et al., 1999) and L. fermentum CRL 1386 (Vinderola et al., 2004) were obtained from the CERELA Culture Collection (San Miguel de Tucumán, Argentina). L. paracasei CNCM I-1518 was provided for DANONE Argentina. These strains were cultured for $16 \mathrm{~h}$ at $37^{\circ} \mathrm{C}$ in a sterile Man-Rogosa-Sharpe (MRS) broth (Britania, Buenos Aires, Argentina).

Staphylococcus aureus ATCC 25923 were kindly provided by Mariel Cáceres, Hospital Ángel C. Padilla, Tucumán. Salmonella enterica serovar Typhimurium strain was obtained from the Bacteriology Department of the Hospital del Niño Jesus (San Miguel de Tucumán, Argentina).

Aliquots of $S$. Typhimurium and S. aureus $(200 \mu \mathrm{l})$ from an overnight culture were placed in $5 \mathrm{ml}$ of sterile Brain Heart Infusion (BHI) broth (Britania, Buenos Aires, Argentina) and incubated during 4-5 h to reach exponential grown phase.

\section{Animals and Diet Supplementation}

$\mathrm{BALB} / \mathrm{c}$ mice were provided for CERELA (San Miguel de Tucumán, Argentina) from a closed random bred colony, and maintained in a room with a 12 -h light/dark cycle at $22 \pm 2{ }^{\circ} \mathrm{C}$, feeding ad libitum with conventional balanced food commercial. Mice of each control and test groups were sacrificed by cervical dislocation, and then small and large intestine and intestinal fluids from each mouse were removed for further studies. All animal protocols were preapproved by the Animal Protection Committee of CERELA (CRL-BIOT-LI-2017/3A) and conducted in accordance with the guidelines established by the Consejo 
Nacional de Investigaciones Científicas y Técnicas (CONICET) and the $\mathrm{NHI}^{1,2}$.

Lactobacillus bacteria overnight cultures were grown at $37^{\circ} \mathrm{C}$ in $5 \mathrm{ml}$ sterile Mann-Rogosa-Sharp (MRS) broth (Britania, Buenos Aires, Argentina). The cells were harvested by centrifugation at $5000 \mathrm{~g}$ for $10 \mathrm{~min}$, washed three times with phosphate saline solution (PBS) and resuspended in $5 \mathrm{ml}$ of sterile $10 \%(\mathrm{wt} / \mathrm{vol})$ non-fat milk. Bacterial suspensions were diluted 1:30 in water and administered ad libitum to the mice. The final concentration of probiotics bacteria was $2 \pm 1 \times 10^{8} \mathrm{CFU} / \mathrm{ml}$, a concentration extensively used by our group (Galdeano and Perdigón, 2004; Castillo et al., 2011). These counts were periodically controlled at the beginning of the administration and each $24 \mathrm{~h}$ of dilution in water to avoid modifications of more than one logarithmic unit. The probiotics bacteria were given in $5 \mathrm{ml}$ of sterile $10 \%$ (wt/vol) skim milk powder and resuspended in the drinking water. The volume drank, controlled daily, was 2.5 to $3 \mathrm{ml} / \mathrm{animal} /$ day in both experimental and control animals as was reported previously (Galdeano and Perdigón, 2006; Balcells et al., 2017).

Groups of BALB/c mice from 21, 28, 35, 42, 54, 61, and 180 days old, received $L$. casei CRL 431 (Lc 431), L. paracasei CNCM I-1518 (Lp 1518), upon 7 and 5 days, respectively. These are the time required for an optimal activation of the intestinal immune system for each strain (Galdeano and Perdigón, 2006; de Moreno de LeBlanc et al., 2008; Vélez et al., 2015). Controls included mice that received indigenous Lactobacilli: L. fermentum CRL 1386, or non-Lactobacilli supplementation (conventional diet).

\section{Histological Samples}

The small intestine samples were fixed in PBS-formaldehyde solution $10 \%, \mathrm{pH}$ 7. The organs were rinsed with PBS and fixed for $24 \mathrm{~h}$ in $10 \%$ buffered formalin. After fixation, the tissues were dehydrated and embedded in paraffin, sectioned, stained with hematoxylin-eosin, and examined by light microscopy. A blind histological test of small intestine was done, analyzing 100 intestinal crypts in 5 slices of each organ.

HE stain allows the identification of Paneth cells (PCs) based on their distinctive granule staining pattern.

\section{Analysis of the Large Intestine Microbiota}

Large intestines from the different mice were aseptically removed, weighed and placed in sterile tubes containing $5 \mathrm{ml}$ of peptone water $(0.1 \%)$. The samples were homogenized immediately under sterile conditions, using a microhomogenizer (MSE, England). Serial dilutions of the homogenized samples were performed and aliquots $(0.1 \mathrm{ml})$ of dilutions were spread onto the surface of the following agarized media: Reinforced Clostridial Agar (RCA, Britania, Buenos Aires, Argentina) for total anaerobic bacteria,

\footnotetext{
${ }^{1}$ http://www.iibyt.conicet.unc.edu.ar/files/Reglamento-Formulario-CICUALIIByT.doc. Regulation and forum of the Institutional Committee for the Care and Use of Laboratory Animals (CICUAL) IIByT.

${ }^{2}$ https://grants.nih.gov/grants/olaw/guide-for-the-care-and-use- of-laboratoryanimals.pdf. Guide for the care and use of laboratory animal.
}

Mann-Rogosa-Sharp (MRS Britania, Buenos Aires, Argentina) for total lactobacilli (Britania, Buenos Aires, Argentina), and MacConkey for total enterobacteria. MacConkey and MRS agar were aerobically incubated at $37^{\circ} \mathrm{C}$ for 24 and $48 \mathrm{~h}$, respectively. The other culture media were anaerobically incubated at $37^{\circ} \mathrm{C}$ for $72-96 \mathrm{~h}$.

\section{Ex Vivo Analyses of the Antimicrobial Activity}

According to previous reports showing that high ionic strength of bacterial broths is a major inactivation factor for the microbicidal activity of $\alpha$-defensins and to match the low ionic strength and $\mathrm{pH}$ of the intestinal mucous layer, we used $10 \mathrm{mM}$ sodium phosphate buffer, $\mathrm{pH} 7.4$, in sterile distilled water. This medium does not compromise bacterial growth, as previously reported (Shimoda et al., 1995; Nakajima et al., 2003).

After animals were sacrificed, the small intestines were removed, and their content was collected in sterile tube by passage $0.5 \mathrm{ml}$ of $10 \mathrm{mM}$ sodium phosphate buffer, $\mathrm{pH} 7.4$ along the intestine. Supernatant were then collected after centrifuge at $1300 \times g 4^{\circ} \mathrm{C} 15 \mathrm{~min}$. Exponential growth phase suspensions of S. Typhimurium, S. aureus, L. casei CRL 431, and L. paracasei CNCM I-1518 bacteria were washed twice in $10 \mathrm{mM}$ sodium phosphate buffer $\mathrm{pH} 7.4$, adjusted at $5 \times 10^{6} \mathrm{CFU}$ in $20 \mu \mathrm{l}$ and incubated for $2 \mathrm{~h}$ at $37^{\circ} \mathrm{C}$ in the presence or absence of $100 \mu \mathrm{l}$ of the intestinal fluids obtained from the different mice. Then, each incubation mixtures were serially diluted, spread in duplicate selective agar plates, and incubated at $37^{\circ} \mathrm{C}$ for $18 \mathrm{~h}$, followed by determination of CFU count (Furci et al., 2015). Each assay was repeated three times independently. Results were expressed as the differences in the $\mathrm{CFU} / \mathrm{ml}$ presents before and after the incubation of the bacteria with the intestinal fluids.

\section{Transmission Electron Microscopy Studies}

Approximately $2 \times 10^{8} \mathrm{CFU}$ of $S$. Typhimurium, S. aureus, L. casei CRL 431, and L. paracasei CNCM I-1518 were washed twice in $10 \mathrm{mM}$ sodium phosphate buffer, $\mathrm{pH} 7.4$, and incubated for $1 \mathrm{~h}$ at $37^{\circ} \mathrm{C}$ in the presence or absence of $100 \mu \mathrm{l}$ of the intestinal fluids from the different mice. As positive control, bacteria were incubated in the presence of $20 \mu \mathrm{g} / \mathrm{ml}$ of gentamicin.

The bacteria were then centrifuged at 5,000 $\mathrm{g}$ for $10 \mathrm{~min}$, immersed phosphate-buffered glutaraldehyd and send to the "Centro Integral de Microscopía Electrónica (CIME) INSIBIOUNT-CONICET," for transmission electron microscopy analysis.

\section{Statistical Analyses}

Results are presented as means \pm SEM GraphPad Prism 5.0 software (GraphPad Software Inc., San Diego, CA, United States) was employed to carry out calculations. Results presented are representative of three independent experiments. The statistical significance was determined by one-way analysis of variance (ANOVA), using Kruskal-Wallis test performed with the GraphPad Prism 5.0 software. Comparisons were referred to 

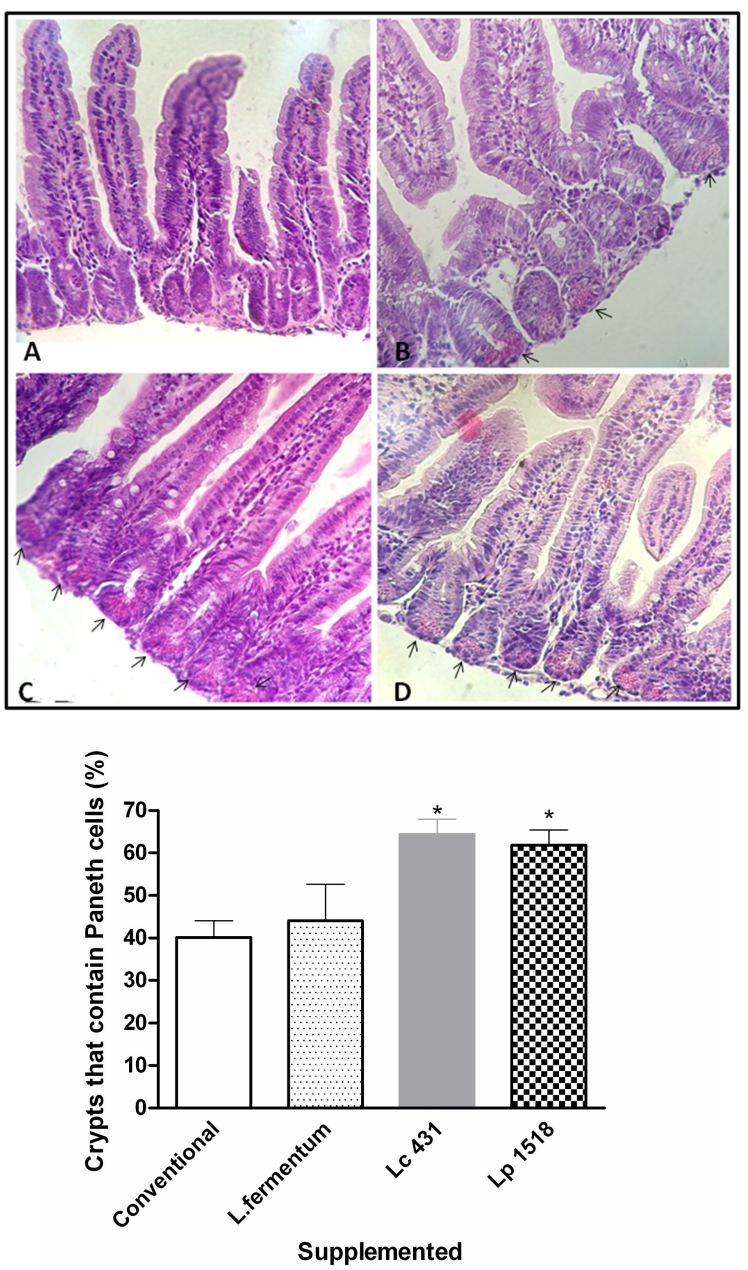

FIGURE 1 | Paneth cells at the base of intestine crypt. Tissue sections of 42 days mice fed with conventional diet (A), Lactobacillus fermentum (B), L. casei CRL 431 (C), or L. paracasei CNCM-I 1518 (D), were stained with hematoxylin and eosin and examined by light microscopy. A blind histological test of small intestine was done by analyzing 100 intestinal crypts in 5 slices of each organ; and the percentages of crypts with positive Paneth cells were determined in each group. Photographs are representative of three independent experiments. Magnification 400x. Arrows point to the Paneth cells in the base of the crypt. The columns bar figure shows semi-quantitatively evaluation for each group. Each bar represents the group mean \pm SEM. Results are representative of three independent experiments. $* p<0.05$.

the mice that received conventional diet. $p$-values $<0.05$ were considered significant.

\section{RESULTS}

\section{Probiotics Oral Administration Increase the Numbers of Paneth Cells at the Base of the Intestine Crypt}

Forty two day old Balb/c mice were fed with: Group I: Conventional diet, Group II: L. fermentum as an intestinal
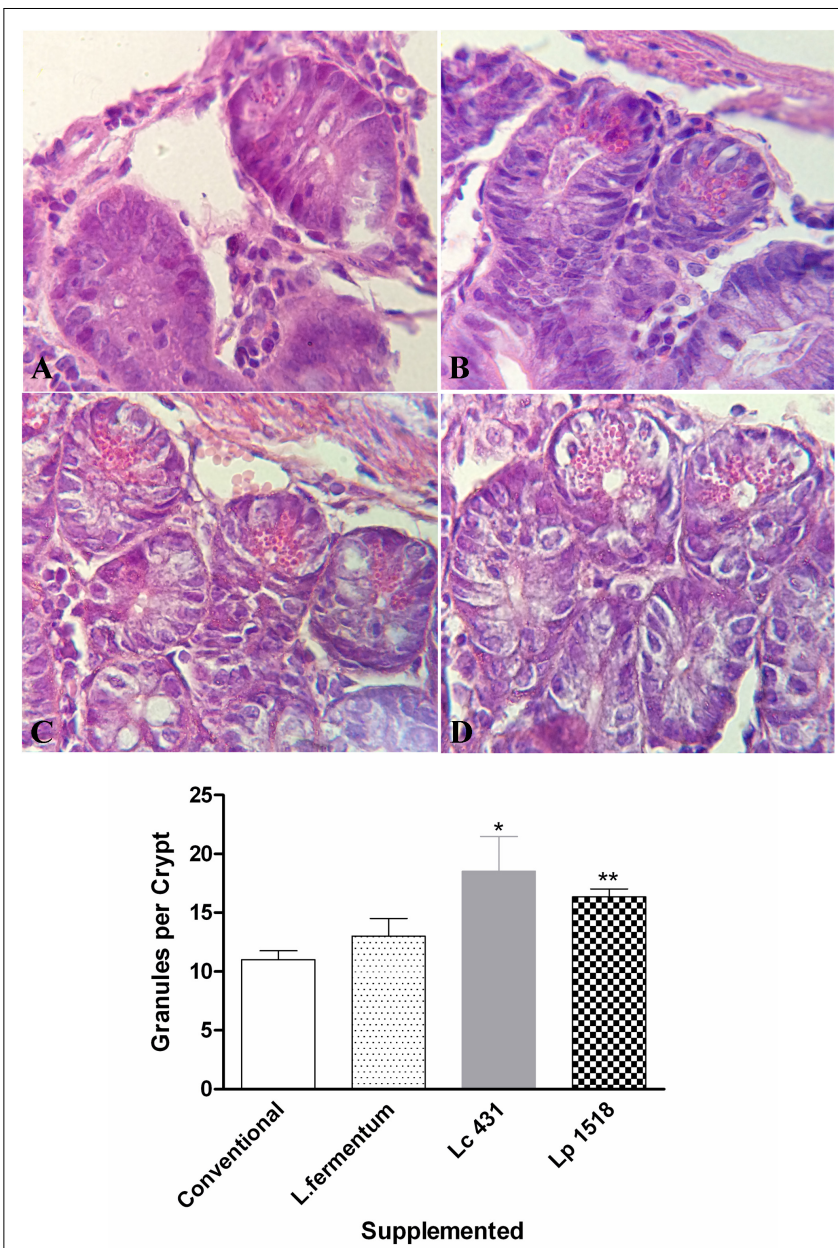

FIGURE 2 | Micrographs of small intestine sections in the different animals' models. Tissue sections of 42 days old mice fed with conventional diet (A), L. fermentum (B), L. casei CRL 431 (C), or L. paracasei CNCM-I 1518 (D) stained with hematoxylin and eosin. Magnification 1000x. Results

(mean \pm SEM) are representative of three independent experiments. The differences were calculated with respect to the control group that received conventional diet $* p<0.05,{ }^{* *} p<0.01$

commensal bacterium, Group III: L. casei CRL 431 (Lc 431), and Group IV: L. paracasei CNCM I-1518 (Lp 1518), for 5 and 7 days, respectively. At the end of this supplementation, animals were sacrificed and a hematoxylin and eosin stain was done in the small intestine tissue sections. We found that mice fed with any of the two probiotics bacteria (L. casei CRL 431 or L. paracasei CNCM I-1518), show a significant increase in the number of crypts with positive Paneth cells in the small intestine $(64.29 \pm 3.58$ and $61.80 \pm 5.31 \%$, respectively), regarding to animals that received conventional diet $(40.10 \pm 3.9 \%)$ (Mean \pm SEM). By contrast, animals fed with a bacteria that is part from the commensal intestinal microbiota, L. fermentum, show values similar to those that received conventional diet $(44.00 \pm 8.62 \%)$ (Figure 1).

Additionally, we observed that mice supplemented with L. casei CRL 431, and L. paracasei CNCM I-1518 presented a significant increase in the number of granules per crypt with 

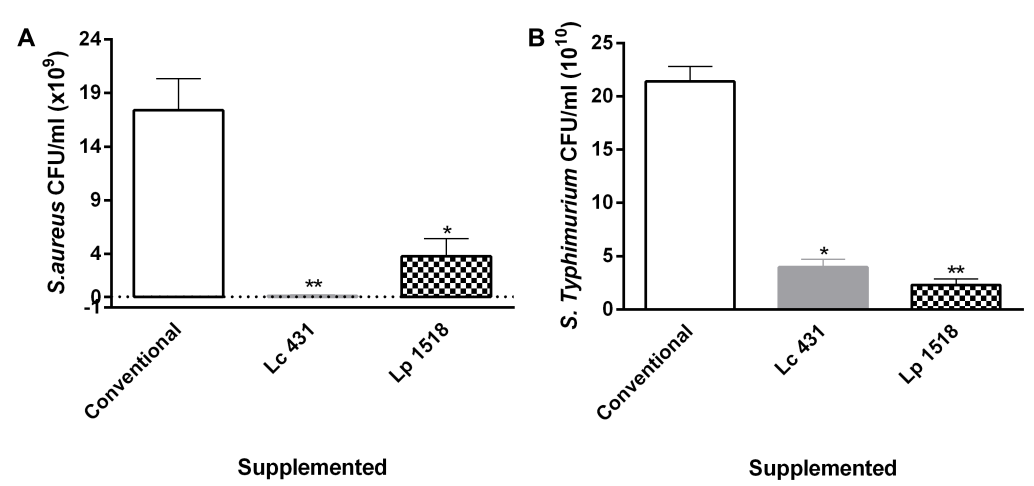

FIGURE 3 | Antimicrobial activity of the animals' intestinal fluids. S. aureus (A) and S. Typhimurium (B) $\left(10^{9} \mathrm{CFU} / \mathrm{ml}\right)$ were incubated for $2 \mathrm{~h}$ at $37^{\circ} \mathrm{C}$, in the presence of the intestinal fluids of 42 days mice fed with conventional diet, L. casei CRL 431 or L. paracasei CNCM-I 1518, for 7 and 5 days, respectively. After the co-incubation, viable bacteria were determined by plate count agar. A set of serial dilutions has been made and samples of each appropriate dilution were spread on top of solidified agar petri plates. Results are expressed as CFU/ml. Results (mean \pm SEM) are representative of three independent experiments. Results were expressed as the differences in the CFU/ml before and after the incubation of the bacteria with the intestinal fluids. The statistics differences were calculated with respect to the control group that received conventional diet $* p<0.05,{ }^{* *} p<0.01$

respect to those that received a conventional diet $(p<0.05$, and $p<0.01$, respectively) or L. fermentum (Figure 2).

\section{Probiotics Oral Supplementation Increases the Antimicrobial Activity in Intestinal Fluids}

The intestinal fluids from adult's mice (42 days old) fed for 7 or 5 days with the different diet were collected, and their antimicrobial activities against pathogen microorganism were studied in vitro. Since supplementation with L. fermentum did not induce a significant increase in the Paneth cells numbers (Figures 1, 2), this group was not included in the following studies.

We observed an important decrease in the CFU of $S$. aureus and $S$. Typhimurium after their incubation with the intestinal fluids of mice fed with $L$. casei CRL 431, compared with those of control mice intestinal fluids $(p<0.01$ and $p<0.05$, respectively). Similar results were found by the supplementation with L. paracasei CNCM-I 1518, in which a reduction of $\sim 4$ and 10 times for $S$. aureus and $S$. Typhimurium, respectively, was observed, with respect to those fed with a conventional diet (Figure 3).

Furthermore, to gain insight into the mechanism by which the intestinal fluids led to the death of the pathogens, transmission electron microscopy was performed on thin sections of bacteria. Control bacteria exposed only to sodium phosphate buffer showed a regular cell shape with intact cell membranes and a homogenous cytoplasm (Figures $4 \mathbf{A}, \mathbf{B}$ ). By contrast, $S$. Typhimurium and $S$. aureus treated with the intestinal fluids of mice fed with Lc 431 or Lp 1518 revealed severe disruption of the wall cells with the later loss of internal cell contents and cell fragmentation. Figure 4 also shows some cell membranes that appeared completely empty of cell contents, and cell debris appeared. We can also observe that the cytoplasm of cells exposed to the intestinal fluids of mice fed with L. paracasei CNCM I 1518, contained electron-dense fibers interspersed with electron translucent areas. Besides, bacteria exposed to the intestinal fluids of mice supplemented with the L. casei CRL 431 showed retractions of the intracellular and membrane ruffling (Figures 4G-I). It is important to mention, that bacteria incubated with the intestinal fluids of mice fed with a conventional diet revealed a slight cellular damage (Figures 4C,D). In this assay, we also include one positive control of cell damage. S. aureus was incubated with gentamicin, which irreversibly bind to specific 30S-subunit proteins and $16 \mathrm{~S}$ rRNA, interrupting protein synthesis and causing the death of the bacteria (Figure 4J).

These results together mirror a strong activation on the antibacterial activity of the intestinal fluids upon supplementation with probiotic lactic bacteria. This antimicrobial activity could be explained by the presence of AMPs in the intestinal fluids, and the attachment of these cationic peptides to the negatively charged bacterial cell surface with the resulting depolarization and cell lysis.

We further analyzed the effect of the intestinal fluids against the probiotics microorganisms, and observed that the intestinal fluids of mice fed with both probiotics had antibacterial activity against themselves: L. casei CRL431 and L. paracasei CNCM-I 1518. This activity was determined by bacterial plate counts and transmission microscopy (Figure 5). Interestingly, these last results highlight the relevance of the antibacterial activity present in the intestinal fluids, not only to protect the villus-crypt microenvironment as the portal of pathogens, but also to maintain the homeostasis in the intestinal microenvironment, avowing the internalization of the whole probiotic bacteria into the intestinal epithelial cells.

\section{The Antimicrobial Activity Induced by Oral Probiotics Is Also Effective in Aging Mice}

Later on, we analyzed the antibacterial activity according to the age of the animals, in the intestinal fluids of mice supplemented 


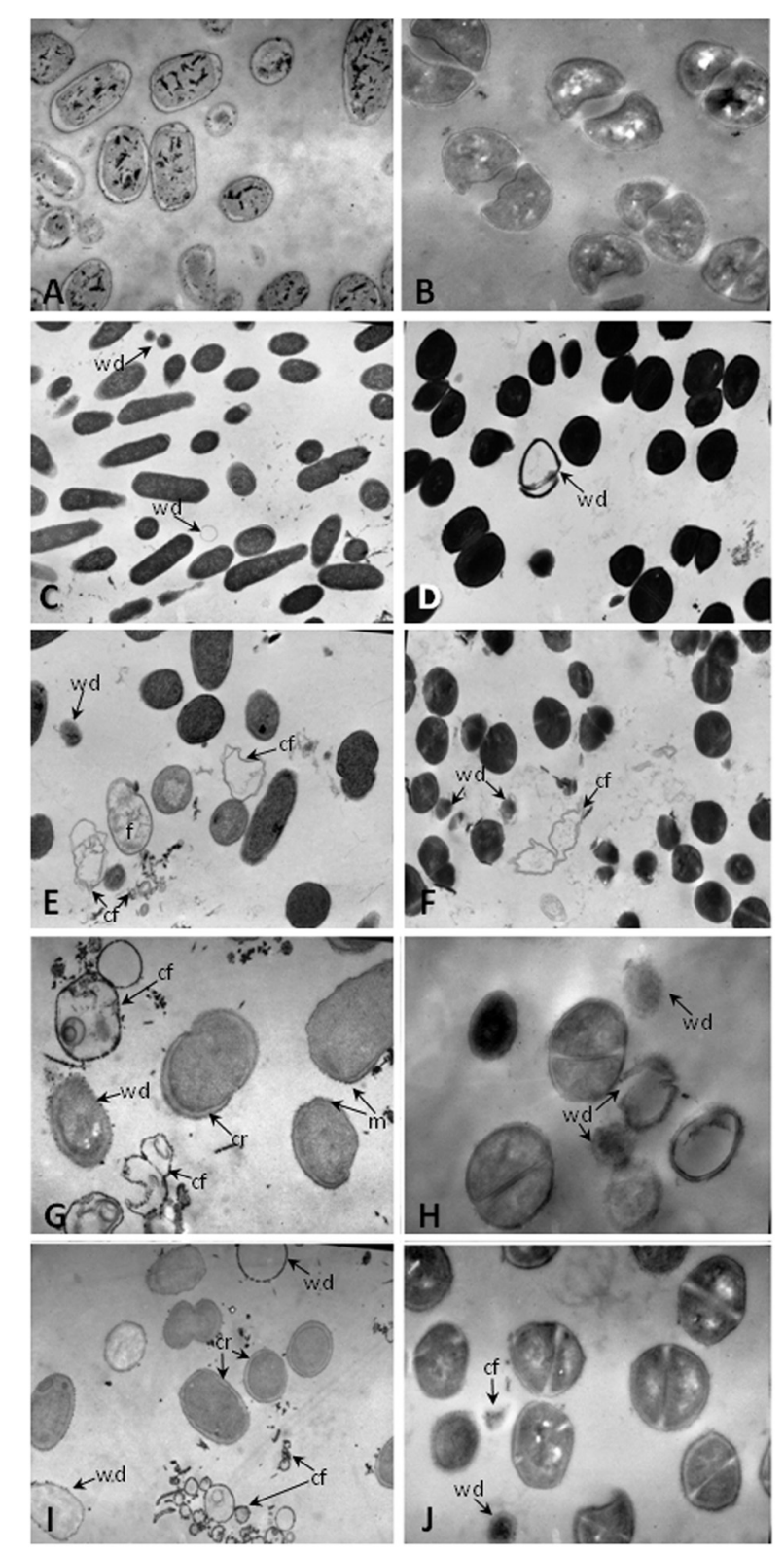

FIGURE 4 | Transmission electron microscopy of pathogens undergoing to intestinal fluids of animals. Approximately $2 \times 10^{8} \mathrm{CFU}$ of $\mathbf{( A , C , E , G , I )}$ S. Typhimurium, $(\mathbf{B}, \mathbf{D}, \mathbf{F}, \mathbf{H}, \mathbf{J}) \mathbf{S}$. aureus were incubated for $1 \mathrm{~h}$ at $37^{\circ} \mathrm{C}$ in the presence of: (A,B) $10 \mathrm{mM}$ sodium phosphate; the intestinal fluids of mice fed with: (C,D) conventional diet, (E,F) L. paracasei CNCM-I 1518, (G-I) L. casei CRL 431; and (J) Gentamicin $20 \mu \mathrm{g} / \mathrm{ml}$. Magnification (C) 7500×; (A,D-F,I) $12.800 \times$; (B,G,H,J) 22.800×. Cr, cytoplasmic retraction; f, electron-dense fibers; cf, cell fragmentation; wd, cell walls disruption; and m, membrane ruffling. their intestinal fluids. In contrast, at 35 days old, an important reduction with respect to control animals, in the CFU number of $S$. aureus, began to manifest $(18.75 \pm 1.46,20.75 \pm 3.46$, and $29.25 \pm 3.75 \times 10^{9} \mathrm{CFU} / \mathrm{ml}$, Mean \pm SEM, for Lc 431, Lp 1518 and Conventional diet, respectively), to became significant at 42 , 54, and 61 days old mice. Most importantly, this antibacterial activity continued slightly high in aging mice (180 days old mice) that received the supplementation with the probiotics lactic bacteria (Figure 6).

Similar results were observed for Salmonella Typhimurium. Thirty five day mice that were previously fed for 7 or 5 days with Lc 431 or Lp 1518, respectively, showed a significant antimicrobial activity against Salmonella, with respect to animals that received conventional diet $(p<0.05)$. Oral supplementation with Lp 1518 increased between 3 to 10 times the Salmonella microbial activity of the intestinal fluids of $35,42,54$, and 61 days old mice, compared with those observed in control mice (Figure 7). Besides, a tendency to diminish the CFU Salmonella count was observed in the presence of the intestinal fluids of 180 days old mice supplemented with both probiotics (Figure 7).

We then analyzed the antimicrobial activity of the intestinal fluids throughout the lives of the mice, against the same probiotics Lc 431 and Lp 1518. Despite the differences were not significant, the number of these microorganisms CFU were lower after exposition of L. casei CRL 431 and L. paracasei CNCM I-1518 to the intestinal fluids of $35,42,54,61$, and also 180 days old mice supplemented for 7 or 5 days with the probiotics, with respect to those control mice (Table 1). All together, these results show the relevance of the oral administration of probiotic bacteria as a tool to deal the growth of pathogens microorganisms and at the same time avoid the overgrowth of the probiotics, from early to old age.

\section{Oral Administration of Probiotics Does Not Modify Large Intestine Microbiota}

With the aim of further characterize the role of Paneth cell stimulation in the mucosal immune system, large intestine microbiota was analyzed. Samples of large intestine belonging to mice from diverse ages (21-180 days old) fed with the Lc 431 or Lp 1518 for 7 and 5 days, respectively, were removed, homogenized, and placed in agar plate medium specific for different bacteria. We did not observe significant differences in the count of total anaerobic bacteria, lactobacilli, and enterobacteria at any of the times analyzed. Although a slight increase was observed at 42 days in the anaerobic bacteria in Lp 1518 fed mice, the differences were not statistically significant (Figure 8). These results demonstrated that probiotics did not significantly modify the large intestinal microbiota population analyzed.

\section{DISCUSSION}

The widespread use of conventional antibiotics has contributed to a huge increase in the number of resistant bacteria. Accordingly, AMPs emerge as an interesting alternative therapy that combines both their antimicrobial and immunomodulatory properties in 


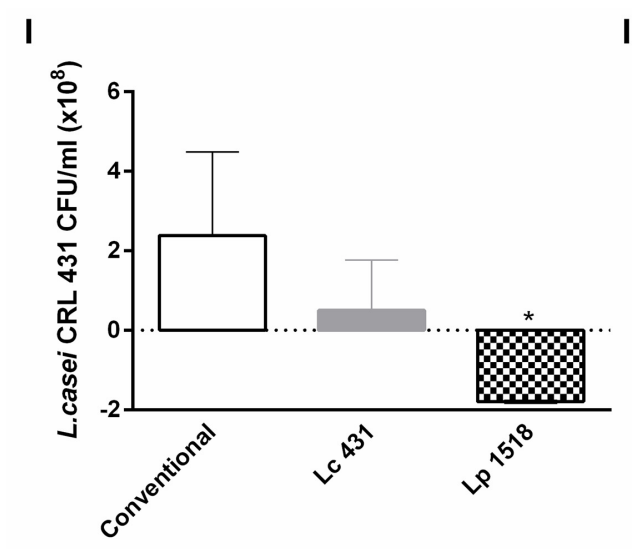

Supplemented

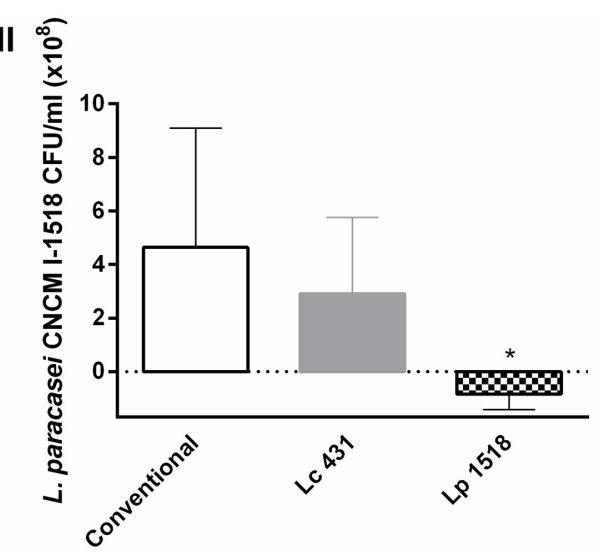

Supplemented

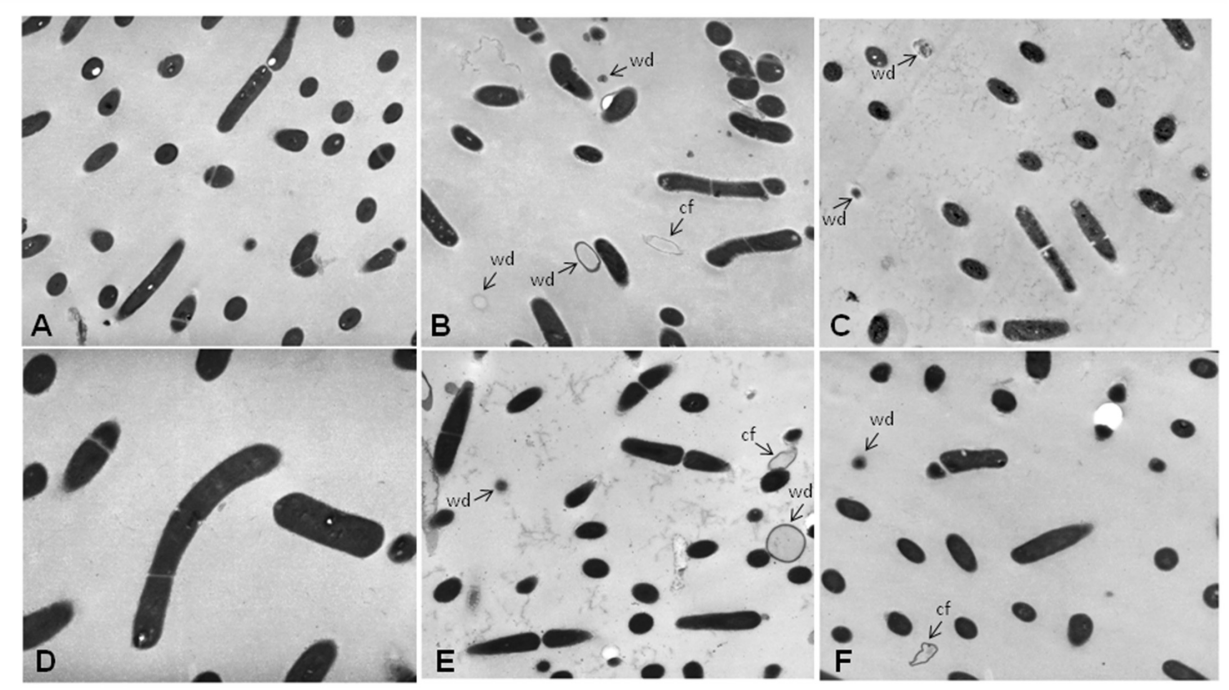

FIGURE 5 | Effect of the animals' intestinal fluids against the probiotics bacteria. In the upper panel L. casei CRL 431 (I) and L. paracasei CNCM-I 1518 (II) $\left(10^{8} \mathrm{CFU} / \mathrm{ml}\right)$ were incubated for $2 \mathrm{~h}$ at $37^{\circ} \mathrm{C}$, in the presence of the intestinal fluids of 42 days mice fed with Conventional diet, L. casei CRL431 or L. paracasei CNCM-I 1518. After the co-incubation, viable bacteria were determined by plate count agar. Results were expressed as the differences in the CFU/ml before and after the incubation of the bacteria with the intestinal fluids. The bars represent the average of 6 determinations, and the SEM is indicated by vertical lines. ${ }^{*} p<0.05$. In the panel below, transmission electron microscopy studies were performed in (A-C) L. casei CRL 431 and (D-F) L. paracasei CNCM-I 1518, incubated for $1 \mathrm{~h}$ at $37^{\circ} \mathrm{C}$ in the presence of the intestinal fluids of mice fed as indicated: Conventional diet (A,D), L. casei CRL 431 (B,E), and L. paracasei CNCM-I 1518 (C,F). Magnification (A-C,E,F: $12.800 \times)$, (D: $7.500 \times)$. cf, cell fragmentation; wd, cell walls disruption.

the same molecule. Several studies both in the laboratory and in the clinic, confirm that emergence of resistance against AMPs is less probable than observed for conventional antibiotics, and provides the impetus to develop AMPs as sentinels to fight pathogens (Kang et al., 2014).

The relevance of AMPs can be illustrated in the fact that these molecules provide plants, fungi, and invertebrates of a robust and crucial defense against microbes without the help of lymphocytes, thymus, or antibodies acquired immunity (Zasloff, 2007). Upon exposure to viable or heat-killed bacteria or to microbial products such as lipopolysaccharide and lipoteichoic acid, Paneth cells release their granules, resulting in increased concentrations of antimicrobials in the intestinal lumen (Porter et al., 2002).
Several AMPs are being developed by the pharmaceutical industry, some of them even have reached preclinical or Phase II studies (Zasloff, 2002). Anyway, the high cost related to the production of these molecules under good manufacturing process (GMP) must not be underestimated.

The present study endorses the use of $L$. casei CRL 431 and L. paracasei CNCM I-1518 as a safe, effective and cost-effective tool to increase in vivo antimicrobial intestinal activity of Paneth cells. Previously, it has been demonstrated that lactic acid bacteria expose their probiotic effects in a dose-dependent manner, being able to kill pathogens, inhibit probably adhesion and invasion of pathogens, inactivate toxins and compete for limited resources successfully (Galdeano et al., 2007; Oelschlaeger, 2010; Johnson and Klaenhammer, 2014; Aktas et al., 2015; Dwivedi et al., 2016). 

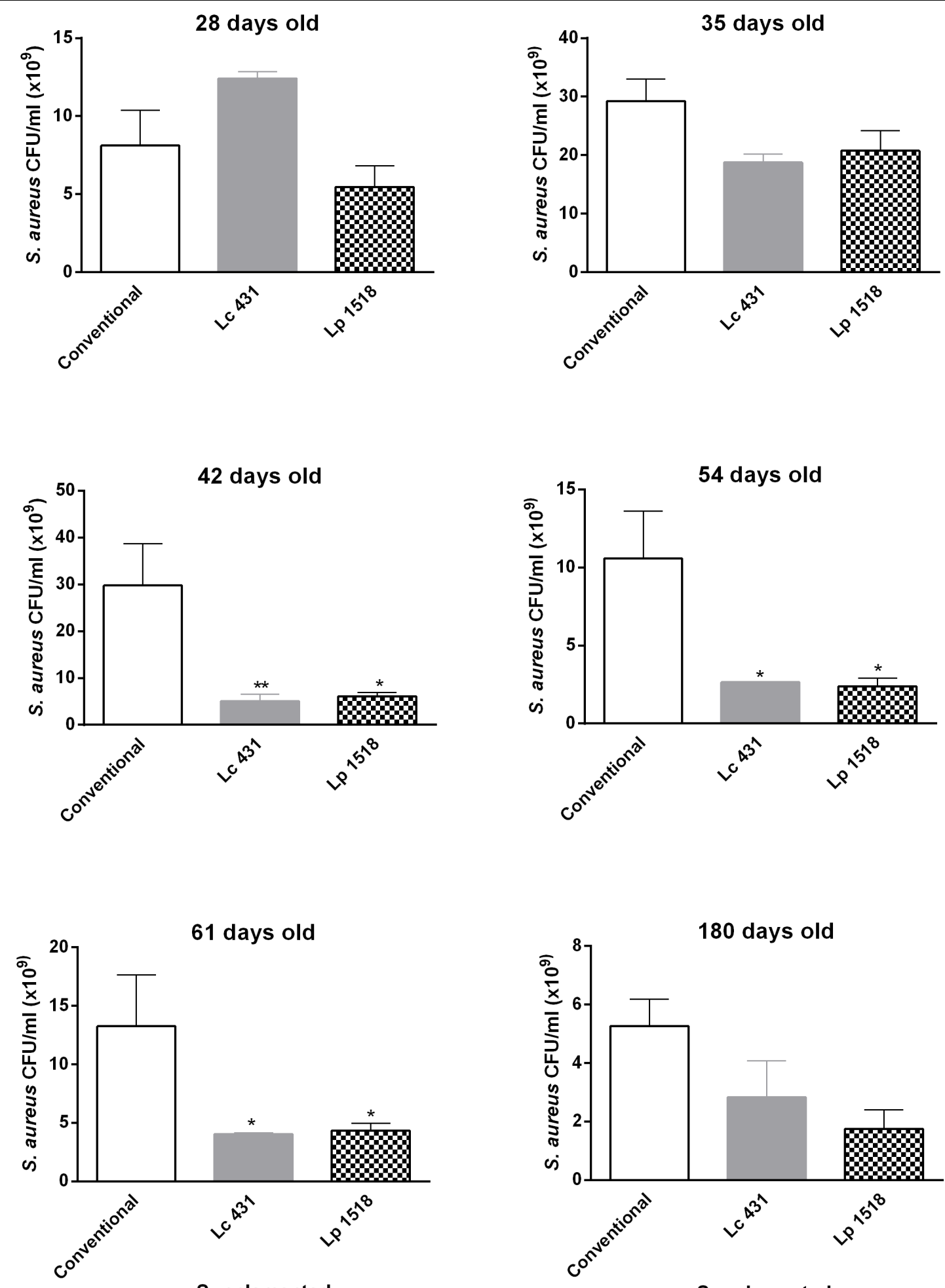

Supplemented

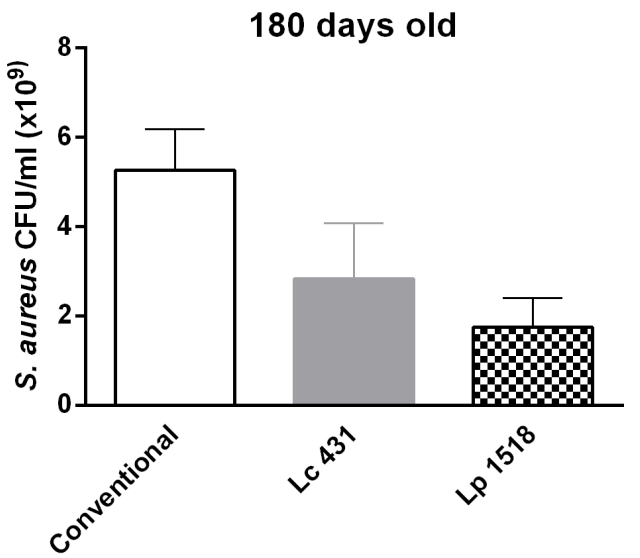

\section{Supplemented}

FIGURE 6 | Antibacterial activity of the intestinal fluids throughout the lives of the animals. Twenty one, 28, 35, 42, 54, 61 , and 180 days old mice were fed with conventional diet, L. casei CRL431 or L. paracasei CNCM-I 1518, for 7 and 5 days, respectively. At this time samples of intestinal fluids were taken and studied for their S. aureus antimicrobial activity after $2 \mathrm{~h}$ of incubation, by plate count agar. Results were expressed as the differences in the CFU/ml before and after the incubation of the bacteria with the intestinal fluids. Results expressed as CFU/ml (mean \pm SEM) are representative of three independent experiments. The statistics differences were calculated with respect to the control group that received conventional diet ${ }^{*} p<0.05,{ }^{* *} p<0.01$. 


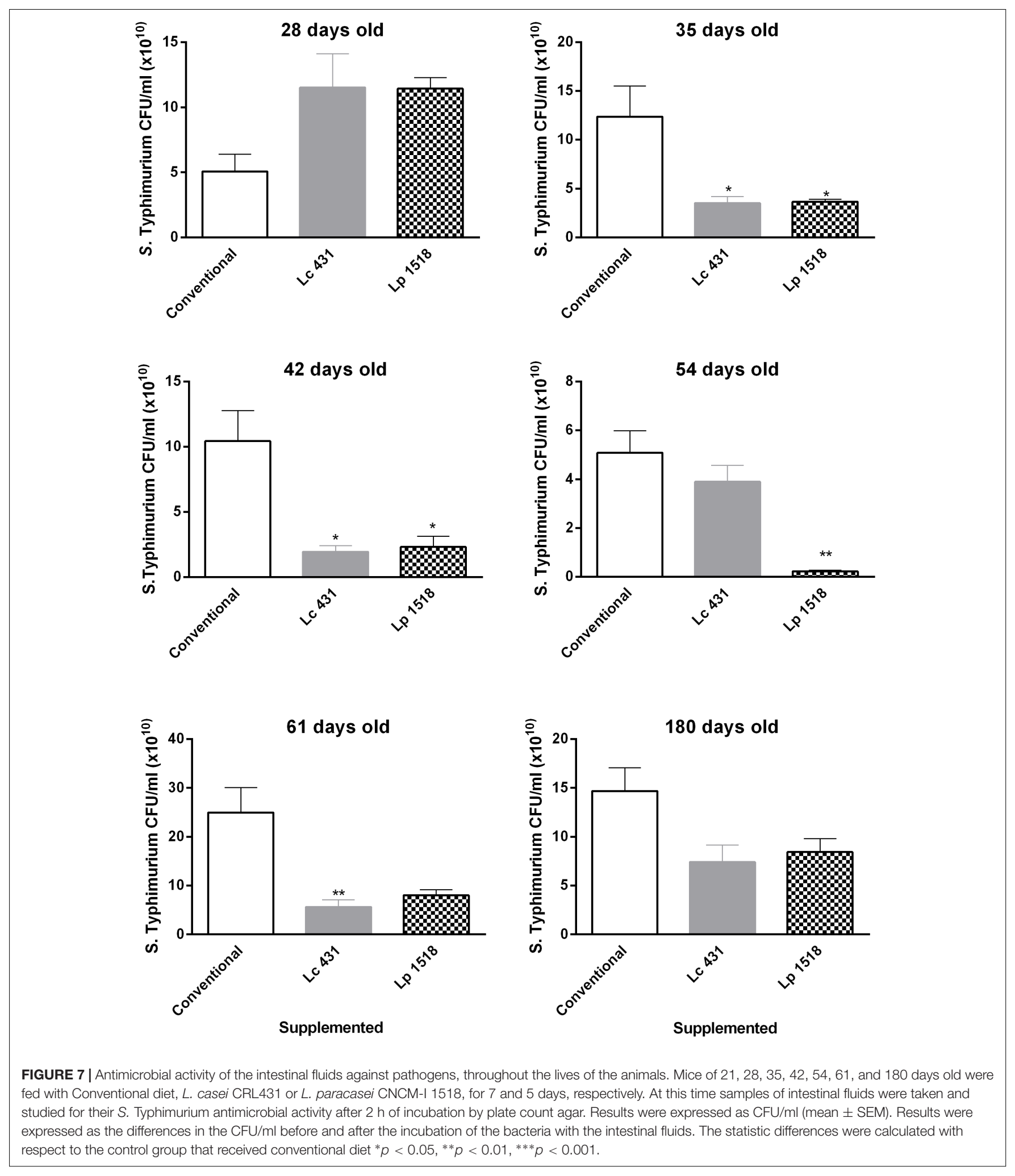

Probiotic bacteria such as Escherichia coli Nissle 1917 and some lactobacilli have been shown to induce AMPs strongly (Wehkamp et al., 2004). E. coli Nissle 1917 (Mutaflor) is the oldest known (in use since World War I, 1917). Its efficacy in maintaining remission in Ulcerative Colitis (UC) has been shown in different placebo-controlled double-blinded studies, and this strain is now recommended as a guideline therapy by the Deutsche Gesellschaft für Gastroenterologie (Kruis et al., 2004). 
TABLE 1 | Intestinal fluid's antibacterial activity against non-pathogen microorganism over the age, in mice fed with different diet.

\begin{tabular}{|c|c|c|c|}
\hline \multirow[t]{2}{*}{ Feeding } & \multicolumn{2}{|c|}{$\begin{array}{l}\text { Microbial activity of } \\
\text { intestinal fluids against }\end{array}$} & \multirow[t]{2}{*}{$\begin{array}{l}\text { Mice days } \\
\text { old }\end{array}$} \\
\hline & $\begin{array}{l}\text { Lactobacillus } \\
\text { casei CRL431 } \\
\left(\mathrm{CFU} / \mathrm{ml} \times 10^{8}\right)\end{array}$ & $\begin{array}{c}\text { Lactobacillus } \\
\text { paracasei CNCM-I } \\
1518\left(\mathrm{CFU} / \mathrm{ml} \times 10^{8}\right)\end{array}$ & \\
\hline \multirow[t]{6}{*}{ Conventional } & $-2.12 \pm 0.07$ & $-0.08 \pm 0.67$ & 28 \\
\hline & $6.25 \pm 1.13$ & $-0.81 \pm 0.35$ & 35 \\
\hline & $11.50 \pm 2.88$ & $5.5 \pm 1.15$ & 42 \\
\hline & $12.83 \pm 3.062$ & $-1.43 \pm 0.23$ & 54 \\
\hline & $18.40 \pm 0.03$ & $18.33 \pm 8.6$ & 61 \\
\hline & $0.21 \pm 0.59$ & $-1.83 \pm 0.25$ & 180 \\
\hline \multirow[t]{6}{*}{ Lc 431} & $2.38 \pm 0.55$ & $0.49 \pm 1.27$ & 28 \\
\hline & $4.2 \pm 0.69$ & $0.67 \pm 0.71$ & 35 \\
\hline & $1.17 \pm 0.42$ & $4.00 \pm 2.02$ & 42 \\
\hline & $1.60 \pm 0.86^{*}$ & $-1.75 \pm 0.08$ & 54 \\
\hline & $16.03 \pm 0.32^{*}$ & $15.27 \pm 7.43$ & 61 \\
\hline & $-1.07 \pm 0.27$ & $-2.20 \pm 0.11$ & 180 \\
\hline \multirow[t]{6}{*}{ Lp 1518} & $0.94 \pm 0.46$ & $-0.57 \pm 0.67$ & 28 \\
\hline & $3.86 \pm 0.73$ & $0.20 \pm 0.55$ & 35 \\
\hline & $3.83 \pm 1.12$ & $-0.83 \pm 0.21^{* *}$ & 42 \\
\hline & $1.66 \pm 1.53^{* *}$ & $-2.07 \pm 0.18$ & 54 \\
\hline & $11.50 \pm 1.89^{* *}$ & $12.83 \pm 0.91$ & 61 \\
\hline & $-1.62 \pm 0.23^{*}$ & $-2.33 \pm 0.03$ & 180 \\
\hline
\end{tabular}

Results were expressed as the differences in the CFU/ml before and after the incubation of the bacteria with the intestinal fluids. Statistic differences were calculated with respect to the control group that received conventional diet ${ }^{*} p<0.05,{ }^{* *} p<0.01$.

In this study, we clearly demonstrated by histological analysis of intestinal tissue, that mice fed with both probiotic bacteria Lc 431 or Lp 1518 increased the number of the Paneth cells at the base of small intestinal Lieberkühn crypt (Figures 1, 2). Eosin intensely stains the basic granules in vertebrates. It has been well documented that the basic content in Paneth cells corresponds to molecules with antimicrobial activity (Porter et al., 2002). Considering this, we then analyzed the antimicrobial activity present in the intestinal fluids in $10 \mathrm{mM}$ sodium phosphate buffer at $\mathrm{pH}$ 7.4, based in previous published results. Porter et al. (1997), assayed the microbicidal activity of recombinant human intestinal defensin 5 (rHD-5) in the presence of different salt concentration and a varied of $\mathrm{pH}$ (5.5 to $\mathrm{pH} 8.5$ ). The authors observed that for wild-type $S$. Typhimurium, the activity of rHD5 at $\mathrm{pH} 8.5$ did not differ from the activity observed at $\mathrm{pH} 7.4$. In contrast, at pH 5.5 defensin activity was reduced, even though bactericidal action was still detectable. Paneth cells are located in the small intestine, where the $\mathrm{pH}$ changes from $\mathrm{pH} 5$ to $\mathrm{pH} 8$ from the proximal to the distal end. These changes in $\mathrm{pH}$ could affect the activity of AMPs by modifying either the peptide or its target.

We observed a strong decrease in the CFU/ml of $S$. Typhimurium and $S$. aureus by plate count agar, after the incubation of the pathogens in presence of the intestinal fluids of mice fed with both Lc 431 and Lp 1518 (Figure 3). These results suggested that intestinal antimicrobial activity (defined by us as a change in the growth kinetic of the pathogen or the probiotics bacteria) can be stimulated in vivo by oral probiotics to display a potent killing effect. Anyway, it cannot be discarded that the metabolites produced upon the probiotic ingestion or the intestinal microbiota itself, could also be contributing to the observed effect.

Many hypotheses have been proposed about the mechanism of action of AMPs. The widespread known, based on their cationic and amphipathic nature, resides in the peptides interacting with cytoplasmic membrane, fatal depolarization and creation of physical holes that cause leakage of cytoplasmic content and widespread cell fragmentation (Zhang et al., 2010; Mukherjee et al., 2014). Accordingly, we observed strong damage in $S$. Typhimurium and $S$. aureus pathogens with clear loss of cell membrane integrity and cell wall fragmentation (Figure 4) after exposition them with the intestinal fluids of mice fed with Lc 431 and Lp 1518, by electron microscopy. By contrast, no damage of bacteria was observed when they were incubated in the presence of medium with low concentration of salts (control). These findings confirm AMPs release by Paneth cell as an active barrier to kill microorganisms, reduce translocation of pathogens across mucosal and prevent enteric infection. Moreover, the destruction of microorganisms by AMPs would be the link between the microbicidal activity and the stimulation of the immune response attributed to AMPs. The generation of pathogen-associated molecular patterns (PAMPs), such as cell wall degradation products or unmethylated microbial DNA, would promote the recruitment of innate immunity masters and APC activation (Rivas-Santiago et al., 2015) as well as amplify even more the release of inducible AMPs by Paneth cells. The effective epithelial responses to bacterial infection would prevent or reduce the frequency of focal neutrophilic infiltration and crypt abscess and minimize the establishment of potential portals of entry for microbes. Our results suggest the increase in the antibacterial activity of the intestinal fluids of mice, would be others of the mechanism by which probiotics protects against Salmonella infection. In that regards, we have previously demonstrated that $L$. casei CRL 431 increase animal survival, decrease pathogen spreading outside the intestine and local inflammatory response (de LeBlanc Ade et al., 2010; Castillo et al., 2011, 2013).

We also analyzed the antibacterial activity against the same probiotics bacteria. Interestingly, we observed fewer recounts of Lc 431 and Lp 1518 when those bacteria where incubated with the intestinal fluids of animals supplemented with both probiotics, in comparison to conventional diet (Figure 5). These results suggest that the growth rate of the bacteria was lower in the presence of intestinal fluids of mice fed with the probiotics than those obtained upon conventional diet. This antimicrobial activity was also revealed by the presence of bacteria fragments by electron microscopy. These fragments could be able to internalize across the intestinal epithelial cells, contact and mediate the activation of the intestinal mucosal immune system elicited by probiotic lactic bacteria. We have previously observed that probiotic bacteria were present in the lumen of the intestine or in the apical surface of the epithelial cells, but inside the intestine cells there were only antigenic particles from bacteria, probably products of the intestinal enzyme degradation. These results suggest that the 


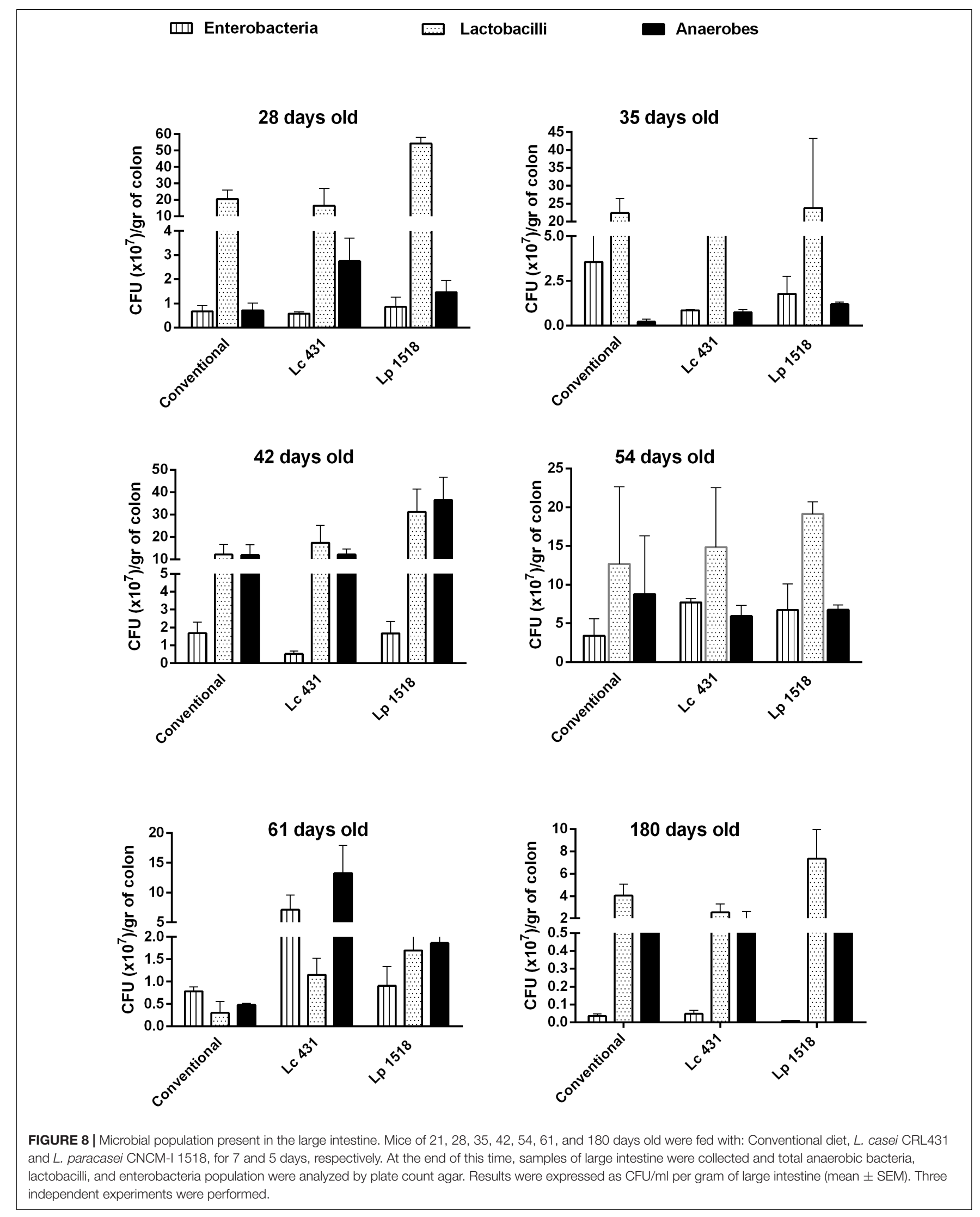


whole bacteria cannot be introduced through the intestine cells and that only the degradation product of the bacteria are able to make contact with the immune cells (Galdeano and Perdigón, 2004). This fact allows the maintenance of the integrity of the epithelial barrier, in contrast with pathogens, which are able to invade the intestinal tissue. Moreover, the fast clearance of these particulate antigens from the gut would allow the regular consumption of probiotics without adverse effect to the host.

A pending challenge for immunologists is how to achieve an efficient stimulation of the immune system in elder people. With this in mind we analyzed whether probiotics can strengthen intestinal barrier by increasing antimicrobial activity in the intestinal fluids throughout the lives of the mice. Importantly, 52 and 61 day old animals supplemented for 5 and 7 days with L. casei CRL 431 and L. paracasei CNCM I-1518, respectively, displayed a clear reduction in the number of both pathogens studied, $S$. aureus and $S$. Typhimurium (Figures 6, 7). Oral administration of probiotics increased the intestinal antimicrobial activity when administered in young mice (35-42 days old) but also in elder animals, providing an effective shield against Gram (+) and Gram (-) pathogens.

In this sense, the role of Paneth cells and the intestinal AMPs to avoid intestinal bacterial translocation was firstly reported by Salzman et al. (2003) in an HD-5 transgenic mice. Besides, Vaishnava et al. (2008) demonstrated that the expression of MyD88 in Paneth cells is sufficient to limit Salmonella penetration across the mucosal barrier and systemic dissemination. Later on, Teltschik et al. (2012) associated the lack of Paneth cell function, especially $\alpha$-defensins HD5 and HD6 to decrease mucosal microorganism killing, bacterial overgrown, translocation and systemic inflammation. Moreover, the slightly antimicrobial activity observed in Table 1, is really interestingly because it allows that probiotics can be use as adjuvants of the immune response at different ages, without the risk of an overgrown lactic acid bacteria.

In the intestinal lumen, commensal bacteria colonize and elicit beneficial effects in the host. That requires a complex and fine-tuned function of AMPs involved not only in removing pathogens but also in establishing symbiosis with the normal intestinal microbiota (Nakamura et al., 2016). After probiotic oral administration we did not observe with respect to animals fed with a conventional diet, differences in the number of total population of enterobacteria, anaerobes and lactobacillus in the large intestine (Figure 8). However, an extensive study of the large intestine microbiota composition should be performed by sequencing the V4 region of bacterial $16 \mathrm{~S}$ ribosomal RNA gene, a revolutionary and useful technique to detect diversity and abundance of the microbiome.

Importantly, our results suggest probiotics were able to increase the killing of the pathogens without modify the

\section{REFERENCES}

Acurcio, L. B., Sandes, S. H. C., Bastos, R. W., Sant'anna, F. M., Pedroso, S. H. S. P., Reis, D. C., et al. (2017). Milk fermented by Lactobacillus species intestinal homeostasis at any of times in which they were administered. The disruption of the critical balance between AMPs and luminal bacteria explains gastrointestinal infections and diseases (Wehkamp et al., 2009). An interesting point will be to identify the AMPs involved in this result. Masuda et al. (2011) demonstrated oxidized $\alpha$-defensin cryptdin- 4 (Crp4) has only minimal or no bactericidal activity against commensal bacterial species. By contrast reduced r-Crp4 had potent bactericidal activities against both commensals and noncommensals. In vivo degradation and inactivation of r-Crp4 before secretion should be an important mechanism to prevent the perturbation of small intestinal microbial homeostasis. Additionally, no RegIII $\gamma$-dependent alterations in the luminal flora were evident in RegIII $\gamma$-deficient mice suggesting that the antibacterial protein was inactivated, degraded, or sufficiently diluted when it reached the intestinal lumen (Nakajima et al., 2003).

The oral administration of probiotics will open a new avenue for the effective stimulation of Paneth cells and the intestinal antimicrobial activity. Oral probiotics can also be effective in a combined therapy to enhance the potency of existing antibiotics in vivo, reducing the doses required and so the appearance of antibiotics resistances. AMPs form an arsenal of weapons to combat microbial pathogens and regulate symbiosis between commensal bacteria and the host mucosa.

\section{AUTHOR CONTRIBUTIONS}

SC and CM-G carried out the microbiological work and the animal studies and wrote the draft of the manuscript. GP, RW, and JDP conceived of the study. SC, CM-G, and GP designed the experiments. SC performed the statistical analyses and prepared the figures. GP revised it for significant intellectual content. All authors read and approved the final version of the manuscript.

\section{FUNDING}

This work was supported by grants from Consejo Nacional de Investigaciones Científicas y Técnicas (CONICET) Argentina (PIP No. 1071 and Dra. Cazorla Res 4822), the Secretaría de Ciencia, Arte e Innovación Tecnológica, Universidad Nacional de Tucumán, Argentina (PIUNT 26D/529), and Agencia Nacional de Promoción Científica y Tecnológica (PICT 2964).

\section{ACKNOWLEDGMENTS}

The authors thank Danone Argentina for providing the strains Lactobacillus paracasei CNCM I-1518.

from Brazilian artisanal cheese protect germ-free-mice against Salmonella Typhimurium infection. Benef. Microbes 8, 579-588. doi: 10.3920/BM2016.0163 Aktas, B., De Wolfe, T. J., Tandee, K., Safdar, N., Darien, B. J., and Steele, J. L. (2015). The effect of Lactobacillus casei $32 \mathrm{G}$ on the mouse cecum 
microbiota and innate immune response is dose and time dependent. PLoS One 29:e0145784. doi: 10.1371/journal.pone.0145784

Aragón, F., Carino, S., Perdigón, G., and de Moreno de LeBlanc, A. (2015). Inhibition of growth and metastasis of breast cancer in mice by milk fermented with Lactobacillus casei CRL 431. J. Immunother. 38, 185-196. doi: 10.1097/CJI. 0000000000000079

Ayabe, T., Satchell, D. P., Wilson, C. L., Parks, W. C., Selsted, M. E., and Ouellette, A. J. (2000). Secretion of microbicidal alpha-defensins by intestinal Paneth cells in response to bacteria. Nat. Immunol. 1, 113-118. doi: 10.1038/77783

Balcells, F., Maldonado-Galdeano, C., Perdigón, G., Mariani, C., and Weill, R. (2017). Effect of yogurt with or without probiotic addition on body composition changes and immune system in an obese model. J. Food Sci. Nutr. 3:22. doi: 10.24966/FSN-0176/100022

Brandl, K., Plitas, G., Mihu, C. N., Ubeda, C., Jia, T., Fleisher, M., et al. (2008). Vancomycin-resistant enterococci exploit antibiotic-induced innate immune deficits. Nature 9, 804-807. doi: 10.1038/nature07250

Brandl, K., Plitas, G., Schnabl, B., DeMatteo, R. P., and Pamer, E. G. (2007). MyD88mediated signals induce the bactericidal lectin RegIII gamma and protect mice against intestinal Listeria monocytogenes infection. J. Exp. Med. 6, 1891-1900. doi: 10.1084/jem.20070563

Cadwell, K., Liu, J. Y., Brown, S. L., Miyoshi, H., Loh, J., and Lennerz, J. K. (2008). A key role for autophagy and the autophagy gene Atg16l1 in mouse and human intestinal Paneth cells. Nature 456, 259-263. doi: 10.1038/nature07416

Castillo, N. A., de Moreno de LeBlanc, A. M., Galdeano, C., and Perdigón, G. (2013). Comparative study of the protective capacity against Salmonella infection between probiotic and nonprobiotic Lactobacilli. J. Appl. Microbiol. 114, 861-876. doi: 10.1111/jam.12074

Castillo, N. A., Perdigón, G., and de Moreno de Leblanc, A. (2011). Oral administration of a probiotic Lactobacillus modulates cytokine production and TLR expression improving the immune response against Salmonella enterica serovar Typhimurium infection in mice. BMC Microbiol. 3:177. doi: 10.1186/ 1471-2180-11-177

de LeBlanc Ade, M., Castillo, N. A., and Perdigon, G. (2010). Anti-infective mechanisms induced by a probiotic Lactobacillus strain against Salmonella enterica serovar Typhimurium infection. Int. J. Food Microbiol. 15, 223-231. doi: 10.1016/j.ijfoodmicro.2010.01.020

de Moreno de LeBlanc, A., Chaves, S., Carmuega, E., Weill, R., Antóine, J., and Perdigón, G. (2008). Effect of long-term continuous consumption of fermented milk containing probiotic bacteria on mucosal immunity and the activity of peritoneal macrophages. Immunobiology 213, 97-108. doi: 10.1016/j.imbio. 2007.07.002

Dwivedi, M., Kumar, P., Laddha, N. C., and Kemp, E. H. (2016). Induction of regulatory $\mathrm{T}$ cells: a role for probiotics and prebiotics to suppress autoimmunity. Autoimmun. Rev. 15, 379-392. doi: 10.1016/j.autrev.2016. 01.002

Fábrega, M. J., Rodríguez-Nogales, A., Garrido-Mesa, J., Algieri, F., Badía, J., Giménez, R., et al. (2017). Intestinal anti-inflammatory effects of outer membrane vesicles from Escherichia coli Nissle 1917 in DSS-Experimental Colitis in Mice. Front. Microbiol. 11:1274. doi: 10.3389/fmicb.2017.01274

Furci, L., Baldan, R., Bianchini, V., Trovato, A., Ossi, C., Cichero, P., et al. (2015). New role for human $\alpha$-defensin 5 in the fight against hypervirulent Clostridium difficile strains. Infect. Immun. 83, 986-995. doi: 10.1128/IAI.02955-14

Galdeano, C. M., de Moreno de LeBlanc, A., Vinderola, G., Bonet, M. E., and Perdigón, G. (2007). Proposed model: mechanisms of immunomodulation induced by probiotic bacteria. Clin. Vaccine Immunol. 14, 485-492. doi: 10.1128/CVI.00406-06

Galdeano, C. M., and Perdigón, G. (2004). Role of viability of probiotic strains in their persistence in the gut and in mucosal immune stimulation. J. Appl. Microbiol. 97, 673-681. doi: 10.1111/j.1365-2672.2004.02353.x

Galdeano, C. M., and Perdigón, G. (2006). The probiotic bacterium Lactobacillus casei induces activation of the gut mucosal immune system through innate immunity. Clin. Vaccine Immunol. 13, 219-226. doi: 10.1128/CVI.13.2.219-226. 2006

Habil, N., Abate, W., Beal, J., and Foey, A. D. (2014). Heat-killed probiotic bacteria differentially regulate colonic epithelial cell production of human $\beta$-defensin2: dependence on inflammatory cytokines. Benef. Microbes 5, 483-495. doi: 10.3920/BM2013.0061
Hooper, L. V., and Macpherson, A. J. (2010). Immune adaptations that maintain homeostasis with the intestinal microbiota. Nat. Rev. Immunol. 10, 159-169. doi: $10.1038 /$ nri2710

Igarashi, M., Nakae, H., Matsuoka, T., Takahashi, S., Hisada, T., Tomita, J., et al. (2017). Alteration in the gastric microbiota and its restoration by probiotics in patients with functional dyspepsia. BMJ Open Gastroenterol. 1:e000144. doi: 10.1136/bmjgast-2017-000144

Johnson, B. R., and Klaenhammer, T. R. (2014). Impact of genomics on the field of probiotic research: historical perspectives to modern paradigms. Antonie Van Leeuwenhoek 106, 141-156. doi: 10.1007/s10482-014-0171-y

Kang, S. J., Park, S. J., Mishig-Ochir, T., and Lee, B. J. (2014). Antimicrobial peptides: therapeutic potentials. Expert Rev. Anti Infect. Ther. 12, 1477-1486. doi: $10.1586 / 14787210.2014 .976613$

Koslowski, M. J., Beisner, J., Stange, E. F., and Wehkamp, J. (2010). Innate antimicrobial host defense in small intestinal Crohn's disease. Int. J. Med. Microbiol. 300, 34-40. doi: 10.1016/j.ijmm.2009.08.011

Kruis, W., Fric, P., Pokrotnieks, J., Lukás, M., Fixa, B., and Kascák, M. (2004). Maintaining remission of ulcerative colitis with the probiotic Escherichia coli Nissle 1917 is as effective as with standard mesalazine. Gut 53, 1617-1623. doi: 10.1136/gut.2003.037747

Maldonado Galdeano, C., Novotny Nuñez, I., Carmuega, E., de Moreno de LeBlanc, A., and Perdigón, G. (2015). Role of probiotics and functional foods in health: gut immune stimulation by two probiotic strains and a potential probiotic yoghurt. Endocr. Metab. Immune Disord. Drug Targets 15, 37-45. doi: 10.2174/1871530314666141216121349

Mallina, R., Craik, J., Briffa, N., Ahluwalia, V., Clarke, J., and Cobb, A. G. (2017). Probiotic containing Lactobacillus casei, Lactobacillus bulgaricus, and Streptococcus thermophiles (ACTIMEL) for the prevention of Clostridium difficile associated diarrhoea in the elderly with proximal femur fractures. J. Infect. Public Health 11, 85-88. doi: 10.1016/j.jiph.2017.04.001

Masuda, K., Sakai, N., Nakamura, K., Yoshioka, S., and Ayabe, T. (2011). Bactericidal activity of mouse $\alpha$-defensin cryptdin- 4 predominantly affects noncommensal bacteria. J. Innate Immun. 3, 315-326. doi: 10.1159/000322037

Morata de Ambrosini, V. I., Gonzalez, S. N., and Oliver, G. (1999). Study of adhesion of Lactobacillus casei CRL 431 to ileal intestinal cells of mice. J. Food Prot. 62, 1430-1434. doi: 10.4315/0362-028X-62.12.1430

Mukherjee, S., and Hooper, L. V. (2015). Antimicrobial defense of the intestine. Immunity 20, 28-39. doi: 10.1016/j.immuni.2014.12.028

Mukherjee, S., Zheng, H., Derebe, M. G., Callenberg, K. M., Partch, C. L., and Rollins, D. (2014). Antibacterial membrane attack by a pore-forming intestinal C-type lectin. Nature 505, 103-107. doi: 10.1038/nature12729

Nakajima, Y., Ishibashi, J., Yukuhiro, F., Asaoka, A., Taylor, D., and Yamakawa, M. (2003). Antibacterial activity and mechanism of action of tick defensin against Gram-positive bacteria. Biochim. Biophys. Acta 5, 125-130. doi: 10.1016/j. bbagen.2003.10.004

Nakamura, K., Sakuragi, N., Takakuwa, A., and Ayabe, T. (2016). Paneth cell $\alpha$-defensins and enteric microbiota in health and disease. Biosci. Microbiota Food Health 35, 57-67. doi: 10.12938/bmfh.2015-019

Nelson, H. S. (2016). Allergen immunotherapy now and in the future. Allergy Asthma Proc. 37, 268-272. doi: 10.2500/aap.2016.37.3966

Oelschlaeger, T. A. (2010). Mechanisms of probiotic actions - A review. Int. J. Med. Microbiol. 300, 57-62. doi: 10.1016/j.ijmm.2009.08.005

Pakdaman, M. N., Udani, J. K., Molina, J. P., and Shahani, M. (2016). The effects of the DDS-1 strain of lactobacillus on symptomatic relief for lactose intolerance - a randomized, double-blind, placebo-controlled, crossover clinical trial. Nutr. J. 15:56. doi: 10.1186/s12937-016-0172-y

Park, M. S., Kwon, B., Ku, S., and Ji, G. E. (2017). The efficacy of Bifidobacterium longum BORI and Lactobacillus acidophilus AD031 probiotic treatment in infants with rotavirus infection. Nutrients 9:E887. doi: 10.3390/nu908 0887

Porter, E. M., Bevins, C. L., Ghosh, D., and Ganz, T. (2002). The multifaceted Paneth cell. Cell. Mol. Life Sci. 59, 156-170. doi: 10.1007/s00018-002-8412-z

Porter, E. M., van Dam, E., Valore, E. V., and Ganz, T. (1997). Broad-spectrum antimicrobial activity of human intestinal defensin 5. Infect. Immun. 65, 2396-2401.

Putsep, K., Axelsson, L. G., Boman, A., Midtvedt, T., Normark, S., and Boman, H. G. (2000). Germ-free and colonized mice generate the same products 
from enteric prodefensins. J. Biol. Chem. 22, 40478-40482. doi: 10.1074/jbc. M007816200

Rivas-Santiago, B., Rivas-Santiago, C., Sada, E., and Hernández-Pando, R. (2015). Prophylactic potential of defensins and L-isoleucine in tuberculosis household contacts: an experimental model. Immunotherapy 7, 207-213. doi: 10.2217/imt. 14.119

Rivas-Santiago, C. E., Hernández-Pando, R., and Rivas-Santiago, B. (2013). Immunotherapy for pulmonary TB: antimicrobial peptides and their inducers. Immunotherapy 5, 1117-1126. doi: 10.2217/imt.13.111

Salzman, N. H. (2010). Paneth cell defensins and the regulation of the microbiome: détente at mucosal surfaces. Gut Microbes 1, 401-406. doi: 10.4161/gmic.1.6. 14076

Salzman, N. H., Ghosh, D., Huttner, K. M., Paterson, Y., and Bevins, C. L. (2003). Protection against enteric salmonellosis in transgenic mice expressing a human intestinal defensin. Nature 422, 522-526. doi: 10.1038/nature01520

Sankaran-Walters, S., Hart, R., and Dills, C. (2017). Guardians of the Gut: enteric defensins. Front. Microbiol. 19:647. doi: 10.3389/fmicb.2017. 00647

Shimoda, M., Ohki, K., Shimamoto, Y., and Kohashi, O. (1995). Morphology of defensin-treated Staphylococcus aureus. Infect. Immun. 63, 2886-2891.

Steinstraesser, L., Kraneburg, U., Jacobsen, F., and Al-Benna, S. (2011). Host defense peptides and their antimicrobial-immunomodulatory duality. Immunobiology 216, 322-333. doi: 10.1016/j.imbio.2010.07.003

Teltschik, Z., Wiest, R., Beisner, J., Nuding, S., Hofmann, C., and Schoelmerich, J. (2012). Intestinal bacterial translocation in rats with cirrhosis is related to compromised Paneth cell antimicrobial host defense. Hepatology 55, 1154-1163. doi: 10.1002/hep.24789

Vaishnava, S., Behrendt, C. L., Ismail, A. S., Eckmann, L., and Hooper, L. V. (2008). Paneth cells directly sense gut commensals and maintain homeostasis at the intestinal host-microbial interface. Proc. Natl. Acad. Sci. U.S.A. 30, 20858-20863. doi: 10.1073/pnas.0808723105

Vélez, E. M., Maldonado Galdeano, C., Carmuega, E., Weill, R., Bibas Bonet, M. E., and Perdigón, G. (2015). Probiotic fermented milk consumption modulates the allergic process induced by ovoalbumin in mice. Br. J. Nutr. 28, 566-576. doi: 10.1017/S0007114515001981

Vinderola, C. G., Medici, M., and Perdigón, G. (2004). Relationship between interaction sites in the gut, hydrophobicity, mucosal immunomodulating capacities and cell wall protein profiles in indigenous and exogenous bacteria. J. Appl. Microbiol. 96, 230-243. doi: 10.1046/j.1365-2672.2004. 02158.x

Wehkamp, J., Harder, J., Wehkamp, K., Wehkamp-von Meissner, B., Schlee, M., and Enders, C. (2004). NF-kB and AP-1 mediated induction of human beta defensin-2 in intestinal epithelial cells by $E$. coli Nissle 1917: a novel effect of a probiotic bacterium. Infect. Immun. 72, 5750-5758. doi: 10.1128/IAI.72.10. 5750-5758.2004

Wehkamp, J., Salzman, N. H., Porter, E., Nuding, S., Weichenthal, M., and Petras, R. E. (2005). Reduced Paneth cell alpha-defensins in ileal Crohn's disease. Proc. Natl. Acad. Sci. U.S.A. 13, 18129-18134. doi: 10.1073/pnas.050525 6102

Wehkamp, J., Stange, E. F., and Fellermann, K. (2009). Defensin-immunology in inflammatory bowel disease. Gastroenterol. Clin. Biol. 33(Suppl. 3), S137-S144. doi: 10.1016/S0399-8320(09)73149-5

Wilson, C. L., Ouellette, A. J., Satchell, D. P., Ayabe, T., López-Boado, Y. S., and Stratman, J. L. (1999). Regulation of intestinal alpha-defensin activation by the metalloproteinase matrilysin in innate host defense. Science 1, 113-117. doi: $10.1126 /$ science. 286.5437 .113

Zasloff, M. (2002). Antimicrobial peptides in health and disease. N. Engl. J. Med. 347, 1199-1200. doi: 10.1056/NEJMe020106

Zasloff, M. (2007). Antimicrobial peptides, innate immunity, and the normally sterile urinary tract. J. Am. Soc. Nephrol. 18, 2810-2816. doi: 10.1681/ASN. 2007050611

Zhang, Y., Lu, W., and Hong, M. (2010). The membrane-bound structure and topology of a human $\alpha$-defensin indicate a dimer pore mechanism for membrane disruption. Biochemistry 16, 9770-9782. doi: 10.1021/bi101512j

Conflict of Interest Statement: The authors declare that the research was conducted in the absence of any commercial or financial relationships that could be construed as a potential conflict of interest.

Copyright (c) 2018 Cazorla, Maldonado-Galdeano, Weill, De Paula and Perdigón. This is an open-access article distributed under the terms of the Creative Commons Attribution License (CC BY). The use, distribution or reproduction in other forums is permitted, provided the original author(s) and the copyright owner are credited and that the original publication in this journal is cited, in accordance with accepted academic practice. No use, distribution or reproduction is permitted which does not comply with these terms. 